\title{
Pedrinho Arcides Guareschi
}

Homenageado

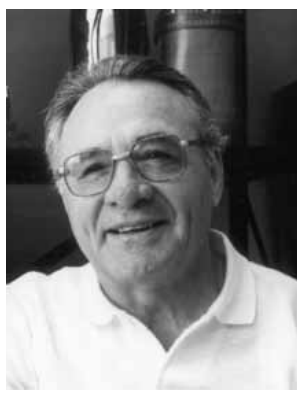

Em sua busca incessante por justiça e cidadania, Pedrinho Arcides Guareschi vem trazendo grandes contribuições para a Psicologia brasileira. O psicólogo e professor é autor e co- autor de numerosas publicações, atuando principalmente no campo da Psicologia social. Guareschi trabalha em especial com os temas mídia, ideologia, representações sociais, ética, comunicação e educação.

Nascido em 1940, no Município de Colorado - que, na época, se chamava Boa Esperança -, no Rio Grande do Sul, cidade com apenas seis mil habitantes, o garoto iniciou, com nove anos, sua trajetória pelo Brasil e pelo mundo em busca de conhecimento. Pedrinho Guareschi estudou em colégio interno, cursou o ensino fundamental e médio, fez graduação em Filosofia, Teologia e Letras e interessou-se por Sociologia e Psicologia, até perceber que sua vocação estava no entremeio das duas, e ali encontrou a Psicologia social crítica, na qual ainda trabalha.

Em meados de 1964, foi ordenado sacerdote, e, como sacerdote, atua até hoje na pastoral das periferias, sempre em sintonia com os movimentos sociais, a exemplo de sua participação na fundação do Movimento dos Sem Terra no Paraná.

Em 1965, Pedrinho concluiu pós-graduação em Sociologia pela Universidade Católica do Rio Grande do Sul (PUCRS). Na década de 70, mudou-se para a cidade de Milwaukee, Estados Unidos, onde concluiu o mestrado em Psicologia Social na Universidade Marquette e doutorado em Psicologia Social e Comunicação na Universidade de Wisconsin. Em Milwaukee, realizou um trabalho de distribuição de refeição para os miseráveis da cidade - prostitutas, bêbados e viúvas - chegando a atender até 300 pessoas ao fim de cada mês. Pedrinho fez seu primeiro pós-doutorado em 1990, no Centro de Estrutura Social e Mudança Social da Universidade de Wisconsin, Estados Unidos. Realizou o segundo pós-doutorado no ano 2002, na Universidade de Cambridge, Inglaterra, quando aprofundou pesquisas nas questões de Psicologia social e comunicação.

Nos anos 90, Pedrinho lecionou na Accademia Alfonsiana, ligada à Universidade Lateranense, em Roma. O professor também colaborou, por vários anos, com a Comissão de Direitos Humanos do Conselho Federal de Psicologia.

Atuou por sete anos como membro efetivo do grupo Ética na TV, implementando a Campanha Quem Financia a Baixaria é contra a Cidadania, do Comitê de Direitos Humanos da Câmara dos Deputados.

Durante 40 anos, foi professor titular, orientador do Programa de Pós-Graduação em Psicologia da Pontifícia Universidade Católica do Rio Grande do Sul, onde hoje é pesquisador CNPq 1-A.

Guareschi está sempre envolvido em atividades acadêmicas, religiosas, educação popular e em movimentos populares. E atualmente, é conselheiro do Instituto Alana.

“Não consigo ver uma Psicologia que não seja social. Aliás, o próprio Freud disse que toda Psicologia é social. Toda prática psicológica carrega consigo uma dimensão ética, valorativa. É dentro desses pressupostos que vivo minha atuação na Academia e nos movimentos sociais. Psicólogo é o que é capaz de auscultar as pulsações da sociedade e, como nada existe sem valores, ver suas dimensões éticas e emancipatórias", resume Pedrinho Guareschi acerca da Psicologia. 